\title{
The development of renewable energy and state policy in improving energy efficiency
}

\author{
Shakizada Niyazbekova ${ }^{1,2, *}$, Saltanat Yerzhanova $^{3}$, Yuliya Tyurina ${ }^{4}$, Mirlan Abilmazhinov $^{5}$, \\ Karl Kyazimov ${ }^{6}$, and Evgeniya Smernitskaya ${ }^{7}$ \\ ${ }^{1}$ Moscow Witte University, Department finance and economy, 115432, 2-I Kozhukhovski p., 12, \\ bd.1, Moscow, Russia \\ ${ }^{2}$ Academy of labor and social relations, Department of Philosophy and Sociology, 119454, Russia, \\ 88, Lobachevskogo \\ ${ }^{3}$ Karaganda State University named after E.A. Buketova, 100009, 28, Universitetskaya street, \\ Karaganda, Republic of Kazakhstan, \\ ${ }^{4}$ Financial University under the Government of the Russian Federation, 125993, 49 Leningradsky \\ Prospekt, Moscow, Russia \\ ${ }^{5}$ Astana International University, Department «Higher school of Economics», 010000,8, Kabanbay \\ batyr avenue, Nur-Sultan, Republic of Kazakhstan \\ ${ }^{6}$ Academy of labor and social relations, Departments of Labor Economics and Personnel \\ Management, 119454, 88, Lobachevskogo, Moscow, Russia \\ ${ }^{7}$ V.I. Vernadsky Crimean Federal University, Department of Public Administration, 295007, 21/4, \\ Sevastopolskaya street, Simferopol, Republic of Crimea
}

\begin{abstract}
This article examines the state policy in the field of electric power industry aimed at increasing energy saving. Taking into account all the pros and cons of classical types of electricity production, more and more attention is paid to new, emerging sources, in particular, biofuels and processing of production and consumption waste. Wind power is an innovation that has received investment for development before, but the previous advanced production has not had much success. Russia and the international community have recognized the advantages of renewable energy sources based on wind over traditional energy sources, and the Russian wind energy industry has become the object of close attention not only of domestic entrepreneurs, but also of foreign companies that consider it as a profitable industry for long-term investment.
\end{abstract}

\section{Introduction}

The energy industry includes wind power, which specializes in converting the kinetic energy created by the movements of air flows into electrical energy using equipment such as wind power plants. The development of wind energy contributes to the creation of clean energy, and also affects the global economy: there is a structural replacement of energy sources. The paper considers the possibilities of application and prospects for the development of wind energy in the country.

\footnotetext{
* Corresponding author: shakizada.niyazbekova@gmail.com
} 


\section{Methods}

At the time of writing, the methods of logical generalization and a systematic approach to the analysis of green bonds were used. When writing the article, we used the data of renewable energy, as well as the state policy in the field of energy efficiency improvement.

\section{Results}

Today, humanity consumes more electricity than ever before, and as a result, it needs new and more efficient means of generating energy, including due to a number of significant disadvantages of traditional sources. To replace the latter, the world community has begun the development of renewable energy sources, among which one of the most significant is wind-based renewable energy sources, the basis for wind energy.

Thus, traditional energy sources in the process of energy production use raw materials that pollute the environment and gradually change the climatic conditions.

The ever-growing population of the population causes a corresponding increase in the demand for electricity, to meet which it is necessary to constantly increase the volume of production, and, as a result, the depletion of stocks of traditional raw materials, such as gas, oil and coal. The best alternative to traditional energy sources is renewable energy sources, especially those associated with wind power.

The Russian Wind Energy Association is an independent non - profit organization founded in 2004 and developing the wind energy market, which aims to provide practical assistance and support to market participants in their entry into the market, development of production, development of wind farms and obtaining orders for wind turbine components, design, construction and logistics services.

\section{Discussion}

Wind energy is based on a powerful and inexhaustible source, it has no harmful emissions into the atmosphere during the production of electric energy, including leading to the greenhouse effect. The advantages of energy based on the movement of air flows include the economy of the occupied area, which can be used together in the management of the economy with other branches of energy.

Along with the positive features, wind energy also has its drawbacks: due to the use of wind as a source, unstable and unregulated electricity generation occurs, large-scale construction of wind power plants (hereinafter referred to as wind farms) or mass purchase of wind turbines require the development of network infrastructure, and noise, visual and electromagnetic effects are on human health and the state of the environment.

Despite the above disadvantages, alternative energy based on wind provides less inconvenience to people and harm to the environment in comparison with traditional energy sources.

For example, in contrast to thermal and nuclear power plants (thermal power plants and nuclear power plants) Wind turbines do not emit carbon dioxide and other harmful mixtures into the atmosphere, in addition, wind power plants emit several times less noise and vibration on the ground than hydroelectric power plants known for this problem (hereinafter referred to as HPPs).

To produce the right amount of energy, wind farms should be built in places where there are constant winds with the required average speed, and as for the necessary infrastructure, any industry needs locally produced components for construction or immediate repair and replacement, both of the plants themselves and certain components. 
The main advantages and disadvantages of wind power are presented in Table 1 .

Table 1. Advantages and disadvantages of wind power.

\begin{tabular}{|l|l|c|}
\hline \multicolumn{1}{|c|}{ Positive aspects } & \multicolumn{1}{|c|}{ Negative aspects } & \multicolumn{1}{c|}{ Advantages } \\
\hline Inexhaustibility of the source & The variability of the source & $\begin{array}{c}\text { The construction of wind } \\
\text { farms in suitable locations }\end{array}$ \\
\hline $\begin{array}{l}\text { Environmental friendliness in } \\
\text { the production process }\end{array}$ & The need for infrastructure & $\begin{array}{c}\text { Faster organization of } \\
\text { energy production }\end{array}$ \\
\hline Small space requirements & $\begin{array}{l}\text { Negative effects on human } \\
\text { health and the environment }\end{array}$ & $\begin{array}{c}\text { Less negative effects } \\
\text { compared to traditional } \\
\text { energy sources }\end{array}$ \\
\hline Autonomous power supply
\end{tabular}

Russia's total installed wind power capacity nearly doubled between 2018 and 2019, reaching 102 megawatts in the latest year observed. From 2010 to 2014, the total installed wind power capacity remained on the level approximately ten times lower, measured at ten megawatts (fig.1).

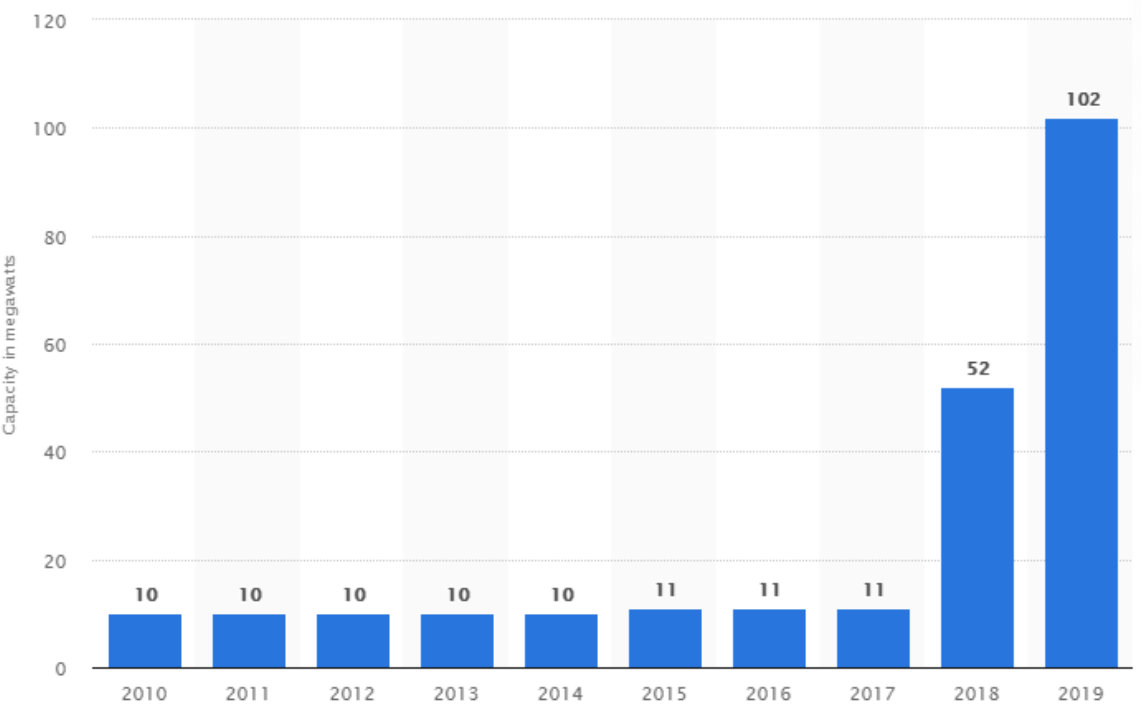

Fig. 1. Total installed wind power capacity in Russia from 2010 to 2019(in megawatts). Source: https://www.statista.com/statistics/1154515/total-wind-power-in-russia/

Russia's onshore wind energy capacity was estimated at 102 megawatts in 2019 . The figure increased by more than nine times between 2017 and 2019 (fig.2).

For the development of wind energy around the world, achieving the indicators was a great start. In the period from the $60 \mathrm{~s}$ to the $80 \mathrm{~s}$ of the XX century, the country's development policy was more focused on the production of energy using traditional energy sources, which received funding in large volumes, than wind energy. Besides mattered was the fact that the capacity of wind turbines inferior capacities of thermal power plants, nuclear and hydro power, which has led to slower development of wind energy.

The regulatory legal acts regulate the issue of localization of facilities operating on the basis of wind energy: the target for the period 2019-2024 is 65\% of the total, which underlines the importance of wind energy for Russia and the interest of relevant state bodies and entrepreneurs in it.

Set targets though, and involve the development of the industry, however, are modest, as practice shows, the development of electricity production figures of the Ministry of 
energy of the Russian Federation unattainable deadlines due to the artificial increase and the impact of foreign policy on the economy and energy of Russia.

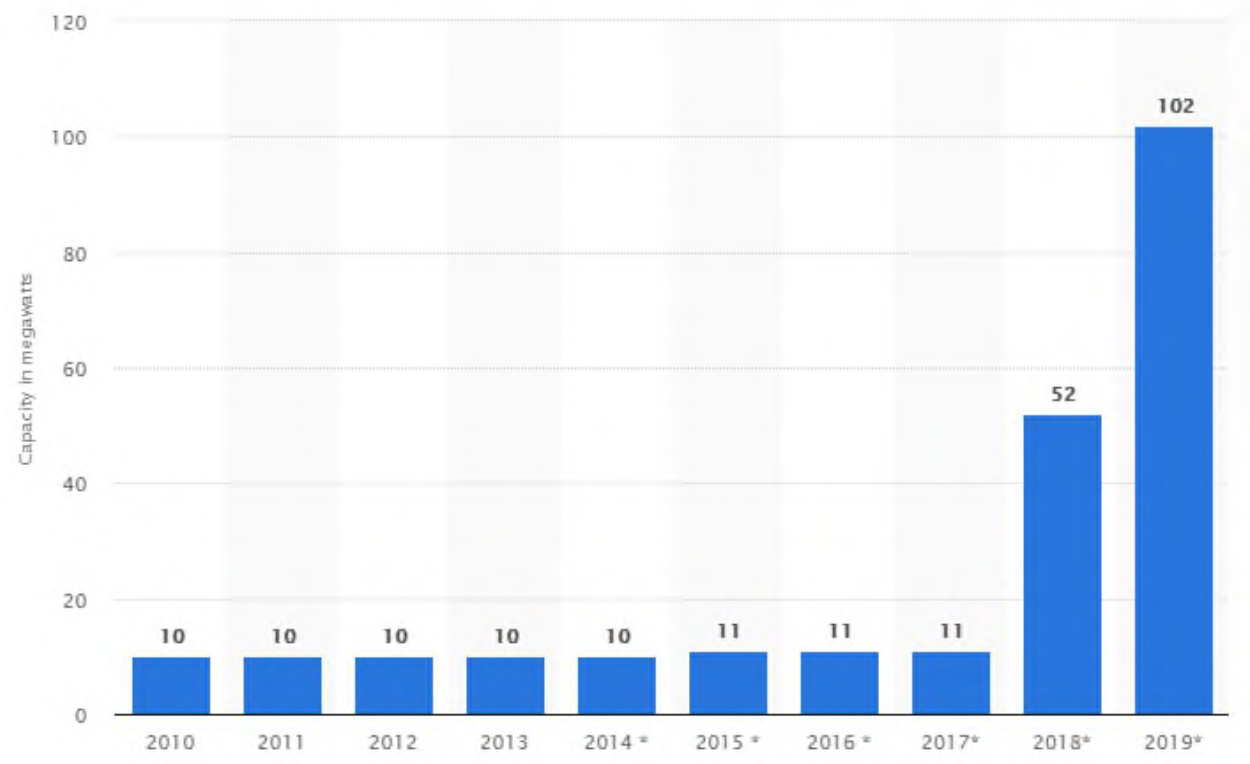

Fig. 2. Onshore wind energy capacity in Russia from 2010 to 2019(in megawatts). Sourse: https://www.statista.com/statistics/1154519/onshore-wind-energy-capacity-in-russia/

State regional and municipal programs for the development of alternative energy are mainly associated with the construction and modernization of existing wind farms in urban settlements and urban districts with no permanent electricity generation and with a population of about 100 thousand people. These goals are set based on the fact that the work on the construction of wind farms is still an introductory, test; the tasks of determining the vector of further development of wind energy in the Russian Federation and providing the population with sufficient electricity are also preserved.

The Republic of Adygea is a test site for the implementation of a long-term strategy for the development of wind energy due to favorable conditions for the placement of wind farms. If the construction project "Adygeiskaya WPP" is successful, the creation of wind farms will be carried out in other regions of the Russian Federation.

The Wind Energy Development Fund was established in 2017 by PJSC Fortum and JSC RUSNANO on a parity basis to invest in the construction of wind farms. The fund is managed by the Wind Energy Management Company, which is equally owned by Fortum and RUSNANO Management Company. The partners intend to invest up to 30 billion rubles in wind energy projects on a parity basis. Another source of financing will be bank loans.

Promising sites for the construction of other wind farms are being considered in a number of different regions, in which the UK "Wind Energy" has concluded partnership agreements with regional authorities, including the Rostov and Saratov regions, the Stavropol Territory and the Republic of Kalmykia. When selecting sites for future wind farms, a number of factors are taken into account, including the wind in the area, as well as logistics, the availability of the local electricity grid, and the degree of willingness of local authorities to cooperate with local authorities. project. 
Today, RUSNANO is actively involved in the development of the Russian wind energy industry, expanding investments in projects for the production of energy based on renewable energy sources. In 2017, the company intended to invest up to RUB 1 billion in equipment localization projects in addition to the joint strategic investment of RUB 30 billion in the construction of wind farms in Russia.

In 2018, RUSNANO and PJSC Fortum planned to jointly invest in the renewable energy infrastructure of the Perm Region in the amount of RUB 15 billion.

Among the commissioned projects of "RUSNANO": Ulyanovsk wind power 35 MW (2018); Ulyanovsk VES-2 50 MW (January 2019); three factories for the production of Russian equipment for wind turbines in Taganrog ("Tower of VRS"), Dzerzhinsk (the plant for the Assembly of nacelles for wind turbines), Ulyanovsk (factory for the production of blades) (2018). Table 2 shows the country's existing wind farms.

Table 2. Operating wind farms of Russia. Source: https://ru.wikipedia.org/

\begin{tabular}{|c|c|c|c|c|}
\hline № & Name & $\begin{array}{l}\text { Installed } \\
\text { capacity, } \\
\text { MW }\end{array}$ & Region & Owner \\
\hline 1 & Adygeya wind farm & 150 & Adygea & JSC "Novamind» \\
\hline 2 & $\begin{array}{l}\text { Ulyanovsk wind farm- } \\
2\end{array}$ & 50,4 & $\begin{array}{l}\text { Ulyanovsk } \\
\text { region }\end{array}$ & $\begin{array}{l}\text { LLC" First Wind Farm } \\
\text { FRV " }\end{array}$ \\
\hline 3 & $\begin{array}{l}\text { Ulyanovsk Wind farm- } \\
1\end{array}$ & 35 & $\begin{array}{l}\text { Ulyanovsk } \\
\text { region }\end{array}$ & Fortum \\
\hline 4 & $\begin{array}{l}\text { Ostaninskaya wind } \\
\text { farm }\end{array}$ & 25 & Crimea & $\begin{array}{l}\text { LLC "Kerch Wind } \\
\text { Park"»» }\end{array}$ \\
\hline 5 & Saka wind farm & 20,83 & Crimea & GUP RK " KGS» \\
\hline 6 & Tarkhankut wind farm & 17,25 & Crimea & GUP RK " KGS» \\
\hline 7 & Presnovodnaya VES & 7,39 & Crimea & GUP RK " KGS» \\
\hline 8 & Donuzlav wind farm & 6,77 & Crimea & GUP RK " KGS " \\
\hline 9 & $\begin{array}{l}\text { Ushakovskaya wind } \\
\text { farm }\end{array}$ & 5,1 & Crimea & $\begin{array}{l}\text { JSC " Kaliningrad } \\
\text { Generating Company» }\end{array}$ \\
\hline 10 & Sudakskaya wind farm & 3,76 & Crimea & GUP RK " KGS» \\
\hline 11 & $\begin{array}{l}\text { East Crimean wind } \\
\text { farm }\end{array}$ & 2,81 & Crimea & GUP RK " KGS» \\
\hline 12 & WES S. Tamar-Utkul & 2,725 & $\begin{array}{l}\text { Orenburg } \\
\text { region }\end{array}$ & OOO "Ecocleaner" \\
\hline 13 & VES Topildi & 1,65 & $\begin{array}{l}\text { Republic of } \\
\text { Bashkortosta } \\
\mathrm{n}\end{array}$ & $\begin{array}{l}\text { Bashkir generation } \\
\text { company }\end{array}$ \\
\hline 14 & Elistinskaya wind farm & 1,2 & $\begin{array}{l}\text { Republic of } \\
\text { Kalmykia }\end{array}$ & \\
\hline 15 & WPP of Orsk & 0,4 & $\begin{array}{l}\text { Orenburg } \\
\text { region }\end{array}$ & OOO "avtotrans-M» \\
\hline 16 & $\begin{array}{l}\text { VES LLC " } \\
\text { AltEnergo» }\end{array}$ & 0,1 & $\begin{array}{l}\text { Belgorod } \\
\text { region }\end{array}$ & LLC " AltEnergo» \\
\hline
\end{tabular}


The role of RUSNANO's business partners in the production of components for wind turbines and wind generators is great: PJSC Severstal and the Danish company Vestas, one of the world's largest manufacturers of equipment for wind power. The Italian company Enel and its Russian subsidiary are building a large wind farm on the harsh and rocky plains northeast of Murmansk.

The farm will have a capacity of 201 MW and will be ready for production by 2022 .

This is one of the largest wind power projects in Russia and the first such project in the Murmansk region.

According to Enel Russia, RUB 3.8 billion was invested in the project in 2017-2019. By 2020, houses for construction workers were built, roads and turbine foundations were built.

The largest share in the installed electricity generating capacity in Russia as of January 29, 2021 was occupied by the thermal power plants, measured at approximately 66.5 percent. The share of the capacity of solar and wind energy plants was measured at only 0.7 percent and 0.42 percent, respectively (fig.3).

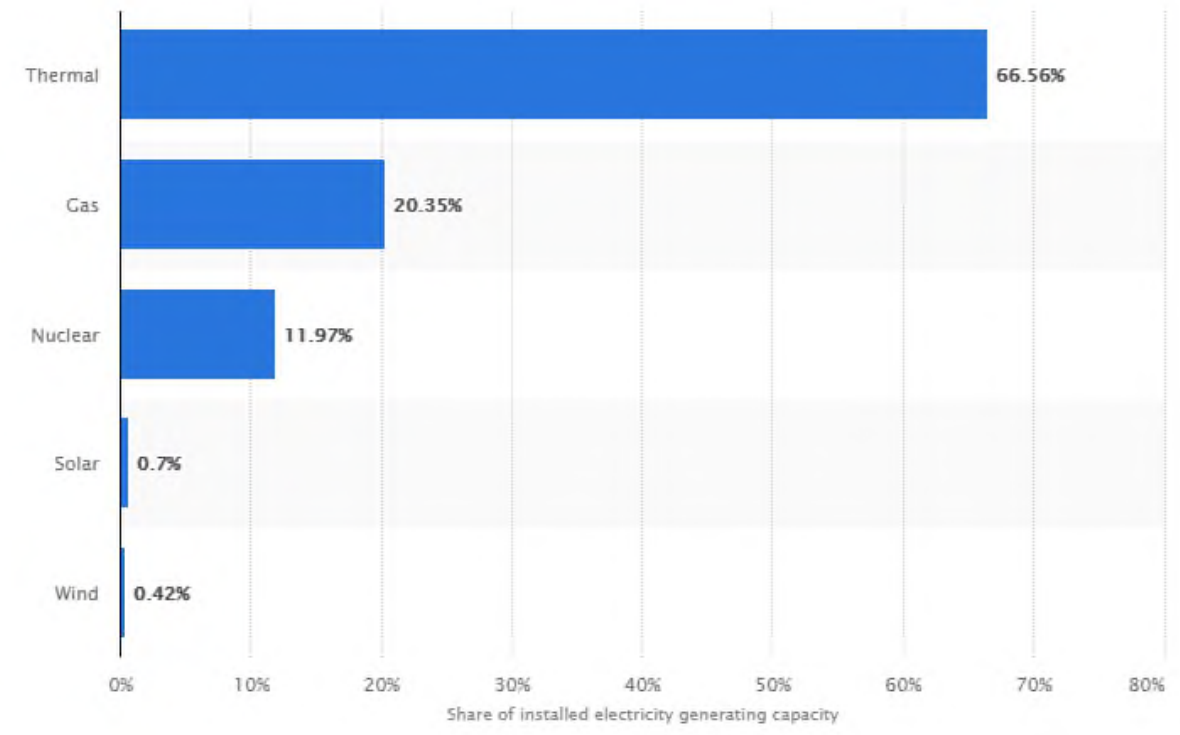

Fig. 3. Distribution of the total installed capacity of sites generating electricity in Russia as of January 1, 2021, by power plant type. Source: https://www.statista.com/statistics/1027465/russia-installedelectricity-generating-capacity-by-source/

According to official data of "NP Market Council" by 2024, the capacity of the domestic wind power industry can reach $3.6 \mathrm{GW}$, and the market turnover can reach 200 billion rubles. In less than ten years, the potential demand for the construction of wind farms in our country, the production of wind turbines, components, operation and maintenance services will approach 400 billion rubles.

Today, three stations have been put into operation. Two of them, more than $200 \mathrm{MW}$, are located in Kalmykia. The second of the new facilities is $50 \mathrm{MW}$ of the first stage of the Cossack wind farm in the Rostov region.

Insufficient rates of wind energy development are determined by the following negative factors that hinder its development:

1. The lack of competence of Russian contractors in the construction of wind power plants, as a result of which there may be a delay in the execution of the relevant works. 
2. High risks of increasing the cost of imported equipment due to changes in the exchange rate, since the costs of the wind farm are calculated in RUB, and the purchase of parts abroad is carried out in foreign currency units.

3. The problem of the lack of financing and investment necessary to fully cover the costs during the construction of all planned wind farms, since the development of wind energy in the initial period requires large monetary investments.

4. The discrepancy between the technical characteristics of the wind power plant and its rated capacity under optimal conditions with a lower output volume and real capacity, which in practice the installation produces due to insufficient wind speed, other weather and climatic conditions.

The widespread introduction of wind energy is also hindered by the factor of time variability of the energy source (wind), which causes some difficulties.

The future of wind energy remains unknown, as it is not yet clear whether domestic production will be able to compete with foreign production in the global market. There is also a huge public sector in the modern Russian economy, which, together with the underdevelopment of the wind energy market, leads to a serious dependence on budget financing and other state assistance.

The main contribution to the global development of wind energy was made by ten national markets, which produce up to $85 \%$ of energy using wind turbines. China accounts for $35 \%$ of the total wind power market, the United States-17\% and Europe - $26 \%$.

Japan, Germany, and the United Kingdom are experiencing a shortage of solar resources, but these countries are world leaders in the field of solar energy.

At the moment, the share of all renewable energy sources in the global energy balance is constantly growing. For example, in Germany, the volume of renewable energy sources reaches $25 \%$ and plans to reach $55-60 \%$ by 2035 , which is proof that wind energy will also receive further development (Table 3).

Table 3. Development of wind energy in the countries.

\begin{tabular}{|l|l|c|l|}
\hline A country & $\begin{array}{l}\text { Number } \\
\text { capacities } \\
\text { increased in 2017, } \\
\text { GW }\end{array}$ & $\begin{array}{l}\text { Current installed } \\
\text { wind power capacity, } \\
\text { GW }\end{array}$ & $\begin{array}{l}\text { The share of wind } \\
\text { energy in the total } \\
\text { national volume of } \\
\text { electricity production } \\
(\%)\end{array}$ \\
\hline Germany & 6,6 & 56,2 & \multicolumn{1}{c|}{13,2} \\
\hline China & 19,5 & 188,2 & 4,8 \\
\hline Russia & - & $143,51 \mathrm{MW}$ & \multicolumn{1}{|c|}{0,12} \\
\hline USA & 7 & 89 & 6 \\
\hline
\end{tabular}

In Germany, which is the leading European market for solar and wind energy, retail electricity prices have more than halved over the past 10 years. Denmark, which has the world's highest share of energy derived from wind and sunlight $(53 \%)$, has one of the lowest electricity prices in Europe, excluding taxes and fees.

\section{Commercial energy}

The Group's main commercial thermal generating facilities are located in the southern European part of Russia. In particular, LUKOIL accounts for $93 \%$ of electricity generation in the Astrakhan Region and 60\% in the Krasnodar Region. 
Table 4. Commercial energy for 2015-2019.

Source:https://www.lukoil.com/Business/Downstream/PowerGeneration.

\begin{tabular}{|l|r|r|r|r|r|}
\hline \multirow{2}{*}{ Name of the company } & \multicolumn{5}{|c|}{ Years } \\
\cline { 2 - 6 } & 2015 & 2016 & 2017 & 2018 & 2019 \\
\hline Installed capacity of the CHPP, MW & 4822 & 4799 & 4632 & 4,584 & 4,522 \\
\hline Electricity supply, million kWh & 20482 & 21704 & 20189 & 19919 & 18307 \\
\hline
\end{tabular}

\section{Renewable}

The main assets of LUKOIL Group in the field of renewable energy located in Russia (four hydropower plants with a total capacity of $291 \mathrm{MW}$, output $868 \mathrm{GWh}$ in 2019).

The LUKOIL group operates three solar power plants in Russia at the Volgograd refinery $(10 \mathrm{MW})$, Romania $(9 \mathrm{MW})$ and Bulgaria $(1.3 \mathrm{MW})$. The plants are built on unused production sites of refineries.

In addition, the LUKOIL Group owns the $84 \mathrm{MW}$ Land Power wind farm in Romania, which enjoys state support for the production of renewable energy.

For the timely development of wind energy in the country needs to create the necessary infrastructure for wind energy, which includes: development of advanced technologies to produce at small sizes large amounts of energy; production of equipment needed for wind turbines; the introduction and installation of wind turbines; the state support at the initial stage of the development of accounting support to small and medium business; oversight of the state in development.

In this case, the Russian territory will be able to form a market for wind energy, which can exist without state assistance and which will be competitive on the world market.

Russia is a country with different climatic conditions, which has a huge potential for the development of renewable energy sources. The benefits of the development of wind energy can increase if both wind turbines and photovoltaic converters (PV) are built on the same sites together with wind farms.

But since Russia has huge raw materials reserves and is the successor of the USSR, which invested a huge amount of money in the development of traditional energy sources, Russia should not neglect the opportunity to use traditional raw materials, since at the moment the Russian energy industry is based on nuclear power plants, thermal power plants and hydroelectric power plants.

While the future is directly linked to renewable energy sources, which have already begun to develop in the Russian Federation, natural resources will be used in various industries in the future, so the Russian energy sector must exist through a combination of both traditional energy sources and renewable energy sources in order to meet the needs of the population, minimize possible costs and keep up with overall development.

\section{Conclusion}

Thus, the following conclusions and suggestions can be made.

The successful development of domestic energy sectors is the key to high-quality and reliable energy supply for citizens not only in Russia, but all over the world. 
With the increasing demand for electricity, humanity is forced to look for additional sources of energy. Wind energy is one of the sources of meeting electricity needs. The main advantages of wind power are a powerful and inexhaustible source.

In the Russian Federation, the development of wind energy began in the 30s of the XX century. During the period of development, both growth and decline were observed, there was no purposeful policy for the development of wind energy; since the country needed large amounts of energy, other sources of energy developed: hydroelectric power plants, nuclear power plants, thermal power plants. Only since the beginning of this century, the Government of the Russian Federation has developed resolutions on the development of wind farms.

On the basis of the Decree of the Russian Federation, many laws have been adopted regulating the development of renewable energy sources, as well as development plans until 2024. Based on the laws and regulations adopted by the state, ROSATOM and RUSNANO have committed themselves to the development of wind energy. They have made commitments to implement the state's plans for the development of wind energy.

The development of wind power in Russia has revealed a number of problems, the main of which are: the incompetence of the Russian contractors, the high cost of imported components, lack of investment, the discrepancy between the nominal power of the wind turbine with its real energy, the lack of competitiveness of the current wind turbine RF power generation in the international market, the lack of stimulating the development of wind energy of the Russian Federation, normative legal acts, the lack of adequate infrastructure for the successful development of wind energy.

To increase the efficiency of the development of the Russian wind energy industry, it is necessary to introduce advanced technologies in the production and installation of wind turbines, domestic production of equipment for wind turbines, and state support at the initial stage of development.

Special attention should be paid to the issues of electricity production, with minimal risks of environmental pollution, and the issues of the depletion of natural resources intended for electricity production.

\section{References}

1. T. Biçen, A. Vardar, A Research on Solar Based Renewable Energy Production, Journal of Biodiversity and Environmental Sciences 12, 59-68 (2018)

2. A. Fiveriati, Y. Yonatan, O. Anne, P.G. Adinuran, Characteristic Biofuel Microalgae Chlorella sp. as Renewable Energy Source 00002 i Published online: 23 September (2020) DOI: https://doi.org/10.1051/e3sconf/202019000002

3. C. Genç, A. Sakalli, I. Stoyanov, T. Iliev, G. Mihaylov, I. Beloev, Development of Wind Energy and the Installed Wind Power Plants in Turkey, E3S Web Conf. 207, 02013 (2020) DOI: https://doi.org/10.1051/e3sconf/202020702013

4. A. Harjanne, J.M. Korhonen, Abandoning the concept of renewable energy, Energy Policy 127 (2018) 10.1016/j.enpol.2018.12.029

5. Z. Tomsic, I. Rajsl, M. Filipovic, Model for the techno-economic analysis of common work of wind power and CCGT power plant to offer constant level of power in the electricity market, E3S Web Conf. 23, 09002 (2017) DOI: https://doi.org/10.1051/e3sconf/20172309002

6. P. Moriarty, D. Honnery, What is the global potential for renewable energy?. Renewable and Sustainable Energy Reviews 16, 244-252 (2012) 10.1016/j.rser.2011.07.151 
7. J. Nahm, Renewable futures and industrial legacies: Wind and solar sectors in China, Germany, and the United States, Business and Politics 19(1), 68-106 (2017) doi:10.1017/bap.2016.5

8. P. Onu, C. Mbohwa, Renewable Energy Technologies In Brief, International Journal of Scientific \& Technology Research 8, 1283 - 1289 (2019)

9. D. Pimentel, M. Herz, M. Glickstein, M. Zefferman, et al, Renewable Energy: Current and Potential Issues, BioScience 52, 1111-1120 (2009) 10.1641/00063568(2002)052[1111:RECAPI]2.0.CO;2

10. N. Tobin, L. Chamorro, Turbulence coherence and its impact on wind-farm power fluctuations, Journal of Fluid Mechanics 855, 1116-1129 (2018) doi: $10.1017 / \mathrm{jfm} .2018 .713$

11. M. Totten, Renewable Energy (2008)

12. G. Withbroe, Solar and stellar Winds, Highlights of Astronomy 8, 525-528 (1989) doi:10.1017/S1539299600008224 